\title{
APLICAÇÃO DE POLÍMERO SUPERABSORVENTE COM O OBJETIVO DE EVITAR O CONGELAMENTO DO CONCENTRADO DE MINÉRIO DE FERRO DURANTE O TRANSPORTE NO INVERNO*
}

\author{
Wen Xuan ${ }^{1}$ \\ Sara Corrent ${ }^{2}$ \\ Grasiela Otto ${ }^{3}$ \\ Armando Corrêa de Araujo ${ }^{4}$
}

\section{Resumo}

Concentrados úmidos de minério de ferro podem se congelar durante o inverno e ficarem presos nos vagões de transporte, dificultando o descarregamento e a operação. Este problema vem sendo observado nas minas de Kryvyi Rih, Ucrânia e Mont-Wright, Canadá, onde o minério de ferro possui respectivamente 10,5\% e 3,5\% de umidade e, durante os invernos rigorosos, as temperaturas podem chegar a valores abaixo de $-20^{\circ} \mathrm{C}$. Nestes locais, uma grande quantidade de energia e tempo tem sido gasta para aquecer e descongelar os vagões. Este artigo mostra que polímeros superabsorventes, como o poliacrilato de sódio, podem evitar o congelamento e facilitar as operações de descarregamento e manuseio, além de possuír fácil aplicação, sendo eficientes quando aplicados apenas no fundo dos vagões, sem a necessidade de se misturar o polímero com o concentrado de minério de ferro.

Palavras-chave: Anti-congelamento; Polímero superabsorvente; Poliacrilato de sódio.

\section{APPLICATION OF SUPERABSORBENT POLYMER TO AVOID FREEZING IN THE TRANSPORTATION OF IRON ORE CONCENTRATE IN WINTER}

\section{Abstract}

Wet iron ore concentrate can be frozen in cold winter. Frozen iron ore concentrate in their wagons makes the discharging and further handling very difficult. This problem has been reported in both Kryvyi Rih, Ukraine and Mont-Wright, Canada, where the iron ore moisture is $10.5 \%$ and $3.5 \%$ respectively, and the severe winter can be as cold as $-20^{\circ} \mathrm{C}$. Currently a huge amount of energy and time is used to heat and defrost the wagons in some customer plants. This article shows that superabsorbent polymers, such as sodium polyacrylate, can avoid freezing and make the handling much easier. The article also shows that the application of the polymer can be simple, as it is already quite efficient when the polymer is just applied on the bottom of the wagons without mixing it with the iron ore concentrate.

Keywords: Anti-freezing; Superabsorbent polymer; Sodium polyacrylate.

1 Research Engineer, ArcelorMittal Mining \& Mineral Processing Research Center, Voie Romaine, 57283, Maizières-lès-Metz, France

2 Student, Universidade Federal de Ouro Preto, Ouro Preto, Minas Gerais, Brazil

3 Student, Universidade Federal de Alfenas, Poços de Caldas, Minas Gerais, Brazil

4 Principal Scientist Mining, ArcelorMittal Mining \& Mineral Processing Research Center, Voie Romaine, 57283, Maizières-lès-Metz, France. 


\section{INTRODUCTION}

When wet iron ore concentrate is transported by railways in cold winter, it can be frozen and its discharging becomes very difficult. This phenomenon results in the loss of transported raw material and productivity. Sometimes the customers need to spend considerable time and energy to heat the wagons.

Two cases are studied in this article. One case is the transportation of iron ore concentrate from Kryvyi Rih, Ukraine to Galati, Romania, which takes 120 hours. This concentrate is also shipped to Ostrava, Czech Republic and Dąbrowa Górnicza, Poland, where the same problem have been reported. The other case is about the concentrate transported from Mont-Wright, Canada to Port Cartier, Canada, which takes 12 hours. In both cases the temperature in winter can be as low as $-20^{\circ} \mathrm{C}$.
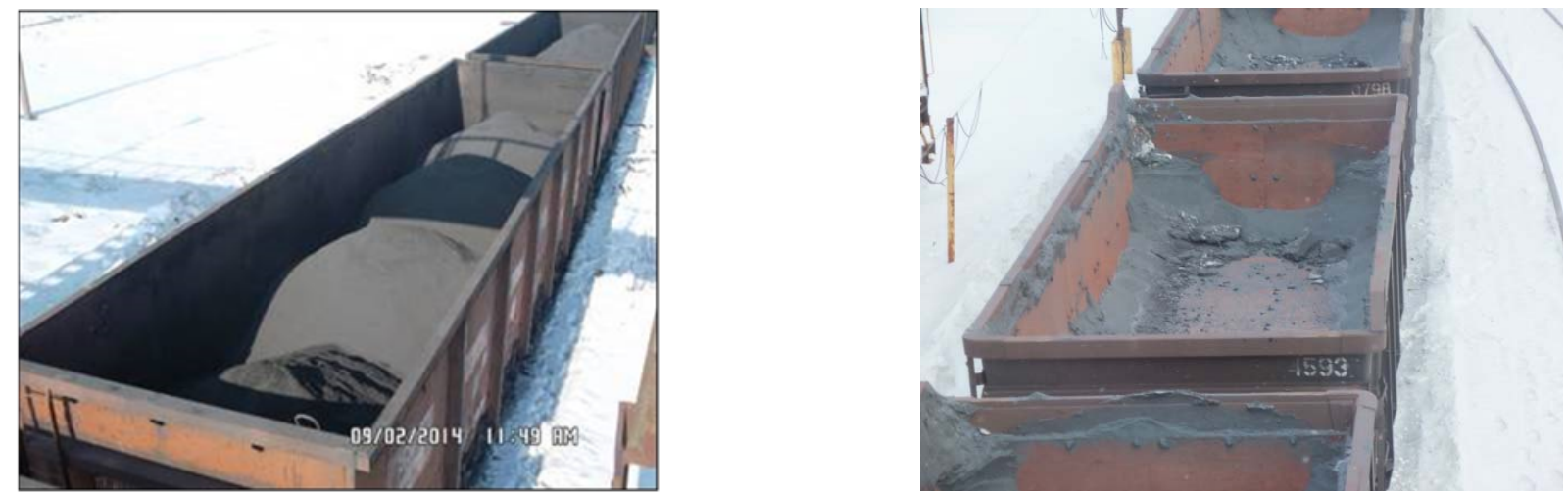

Figure 1: Wagons charged with iron ore from Kryvyi Rih, Ukraine to Galati, Romania (left)

Figure 2: Wagons after dumping in Port Cartier, Canada (right)

In Galati, in order to discharge the frozen iron ore concentrate, huge energy is spent to heat the wagons by natural gas followed by significant demurrage cost. In Port Cartier, residual iron ore concentrate that remains in the railcar after dumping is not negligible. Therefore, efforts have been made to test anti-freezing chemicals, especially sodium polyacrylate, to improve discharging. Bishofite solution was also tested for the application in Ukraine.

\section{MATERIALS AND METHODS}

\subsection{Iron ore concentrate from Kryvyi Rih}

This concentrate ("Kryvyi Rih concentrate" below) has in average 10.5\% moisture. It is mainly magnetite with small amount of hematite. The gangue minerals are quartz, ilmenite, siderite, grunerite/cummingtonite series, chamosite, biotite and magnesiumrich carbonates.

Table 1 presents the chemical assay of a typical Kryvyi Rih concentrate. Its negative loss of ignition ("LOI") is due to the high content of $\mathrm{Fe}^{2+}$ in the magnetite concentrate.

Table 1: Chemistry of a typical Kryvyi Rih magnetite concentrate sample

\begin{tabular}{|c|c|c|c|c|c|c|c|c|c|c|c|}
\hline $\begin{array}{c}\mathrm{Fe} \\
(\%)\end{array}$ & $\begin{array}{c}\mathrm{Fe} \mathrm{Mag} \\
(\%)\end{array}$ & $\begin{array}{c}\mathrm{SiO}_{2} \\
(\%)\end{array}$ & $\begin{array}{c}\mathrm{MgO} \\
(\%)\end{array}$ & $\begin{array}{c}\mathrm{Al}_{2} \mathrm{O}_{3} \\
(\%)\end{array}$ & $\begin{array}{c}\mathrm{CaO} \\
(\%)\end{array}$ & $\begin{array}{c}\mathrm{Na}_{2} \mathrm{O} \\
(\%)\end{array}$ & $\begin{array}{c}\mathrm{K}_{2} \mathrm{O} \\
(\%)\end{array}$ & $\begin{array}{c}\mathrm{Mn} \\
(\%)\end{array}$ & $\begin{array}{c}\mathrm{TiO}_{2} \\
(\%)\end{array}$ & $\begin{array}{c}\mathrm{P} \\
(\%)\end{array}$ & $\begin{array}{c}\mathbf{L O I} \\
(\%)\end{array}$ \\
\hline 64,3 & 63,88 & 8,54 & 0,56 & 0,21 & 0,12 & 0,058 & 0,037 & 0,031 & 0,01 & 0,012 & $-2,1$ \\
\hline
\end{tabular}

The particle size distribution ("PSD") of the Kryvyi Rih concentrate was obtained by wet sieving. The results are shown in Figure 3. 


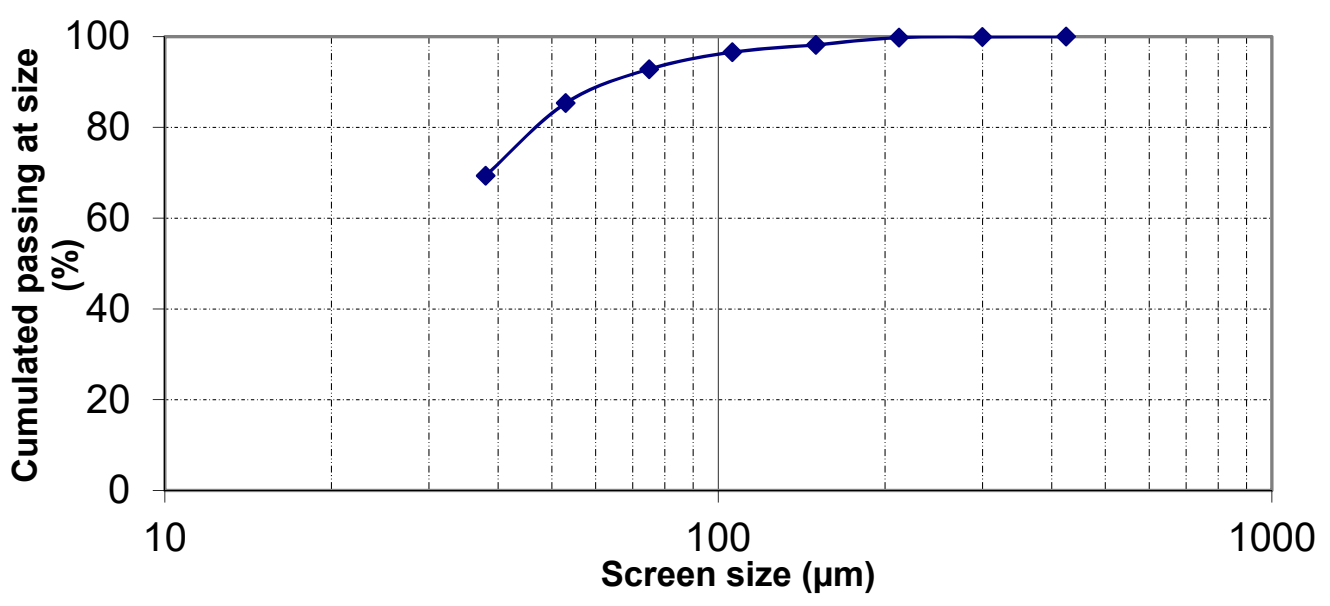

Figure 3: Kryvyi Rih concentrate particle size distribution

\subsection{Iron ore concentrate from Mont-Wright}

This concentrate ("Mont-Wright concentrate" below) has 3.5\% moisture in average. It is mainly hematite with small amount of magnetite and goethite, the main gangue mineral is quartz and there is a small amount of ilmenite in the ore composition. Table 2 presents the chemical assay of a typical Mont-Wright concentrate.

Table 2: Chemistry of a typical Mont-Wright hematite concentrate sample

\begin{tabular}{|c|c|c|c|c|c|c|c|c|c|}
\hline $\begin{array}{c}\mathrm{Fe} \\
(\%)\end{array}$ & $\begin{array}{c}\mathrm{SiO}_{2} \\
(\%)\end{array}$ & $\begin{array}{c}\mathrm{MgO} \\
(\%)\end{array}$ & $\begin{array}{c}\mathrm{Al}_{2} \mathrm{O}_{3} \\
(\%)\end{array}$ & $\begin{array}{c}\mathrm{CaO}^{2} \\
(\%)\end{array}$ & $\begin{array}{c}\mathrm{Na}_{2} \mathrm{O} \\
(\%)\end{array}$ & $\begin{array}{c}\mathrm{K}_{2} \mathrm{O} \\
(\%)\end{array}$ & $\begin{array}{c}\mathrm{Mn} \\
(\%)\end{array}$ & $\begin{array}{c}\mathrm{TiO}_{2} \\
(\%)\end{array}$ & $\begin{array}{c}\mathbf{P} \\
(\%)\end{array}$ \\
\hline 66,02 & 4,95 & 0,08 & 0.38 & 0.11 & 0.026 & 0.009 & 0.046 & 0.37 & 0.019 \\
\hline
\end{tabular}

The particle size distribution ("PSD") of the hematite concentrate was obtained by wet sieving. The results are shown in Figure 4.

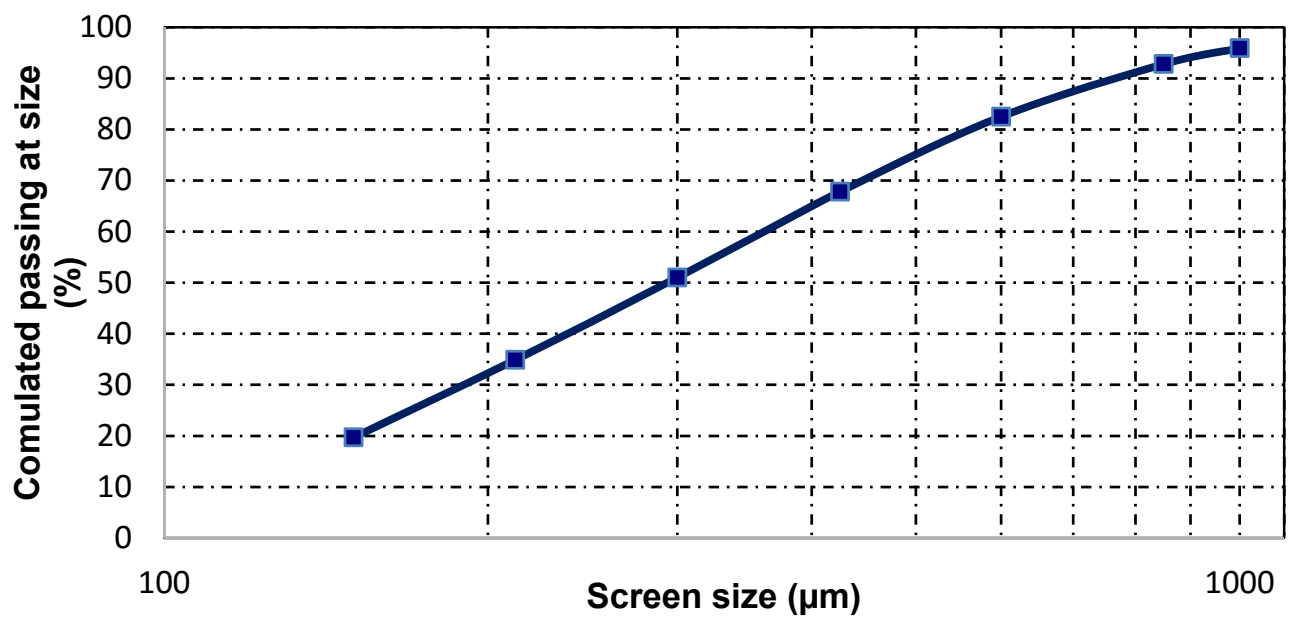

Figure 4: Mont-Wright concentrate particle size distribution

\subsection{Chemical reagent}

Favor Z3050 from Evonik Nutrition \& Care GmbH, super water absorbent based on cross linked sodium polyacrylate was used in this study. 
Bishofite solution is sometimes used to lower the freezing point of water. It was thus also tested for the sake of improving discharging in winter. Its chemical composition can be seen in Table 3.

Table 3: Specification of the Bishofite solution

\begin{tabular}{|c|c|}
\hline Components & Weight \% \\
\hline $\mathrm{MgCl}_{2}$ & $\geq 24$ \\
\hline $\mathrm{NaCl}$ & $\leq 5$ \\
\hline $\mathrm{SO}_{4}{ }^{2-}$ & $\leq 1$ \\
\hline $\mathrm{CaCl}_{2}$ & $\leq 0.5$ \\
\hline Insoluble solids & $\leq 0.2$ \\
\hline
\end{tabular}

\subsection{Equipment}

Freezer LIEBHERR G1223-20 Confort (Figure 5);

Acrylic rectangular prism (Figure 6);

Screens with aperture of $6.3 \mathrm{~mm}$;

Steel boxes;
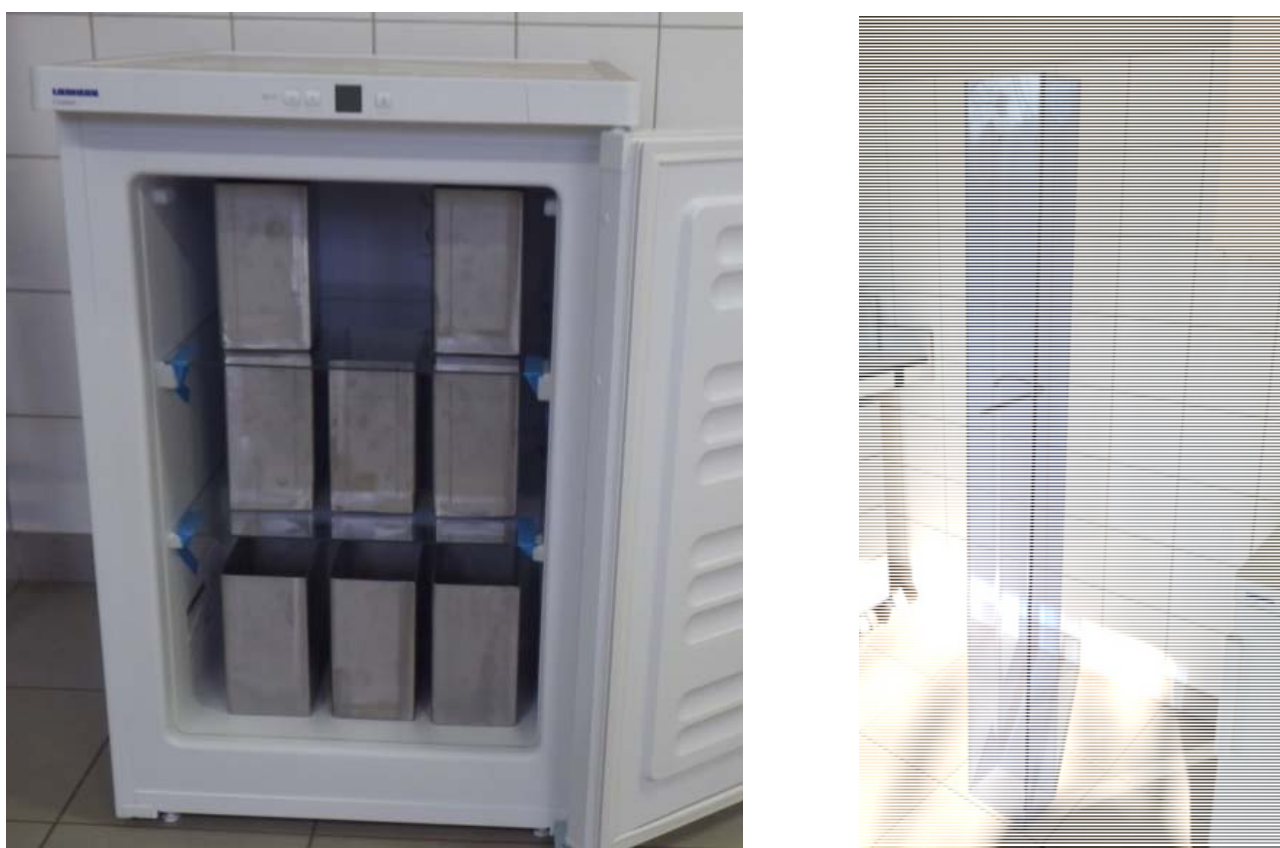

Figure 5: Freezer LIEBHERR G1223-20 Confort (left)

Figure 6: Acrylic rectangular tube (right)

\subsection{Methods}

A new test procedure was developed to evaluate the discharging efficiency at low temperature, using steel boxes to simulate the wagons.

The main steps of the test are the following:

- dry the iron ore concentrate completely;

- mix the dry iron ore concentrate with water, in order to achieve the target moisture;

- add the polymer at defined dosage, either by mixing it with the wet iron ore concentrate, or by putting it onto the bottom of the steel boxes, or simply on the corners of the boxes; 
- $\quad$ put the wet iron ore sample into the steel boxes;

- $\quad$ keep the sample in the freezer "LIEBHERR G1223-20 Confort" at $-20^{\circ} \mathrm{C}$ for 5 days (120 hours);

- take the sample out of the freezer, turn over the steel box and let it fall down from 1 meter onto a flat steel plate;

- $\quad$ in the case of Kryvyi Rih concentrate, the discharged material was screened at $6.3 \mathrm{~mm}$ to quantify the amount of aggregate.

The discharge efficiency is measured by the discharged weight percentage.

The tests were planned for the following objectives:

- To find out the critical freezing moisture, above which the discharging of the iron ore concentrate starts to be a problem;

- To confirm the feasibility of using super water absorbent to avoid freezing of iron ore concentrate;

- To define the optimal dosage of the polymer;

- And to define the way of applying the polymer, especially if the mixing between polymer and iron ore concentrate is a must.

\section{RESULTS AND DISCUSSION}

\subsection{The critical freezing moisture}

It can be seen from Figure 7 that the Kryvyi Rih concentrate can be almost fully discharged until $8 \%$ moisture. From $10 \%$ moisture on, hardly anything can be discharged. Therefore, no treatment is necessary below $8 \%$ moisture. Above $10 \%$ moisture, anti-freezing treatment is a must.

However, the Mont-Wright concentrate can be very well discharged until $8 \%$ moisture. Nevertheless, it is often discharged as a single block which can lead to difficulties in handling.

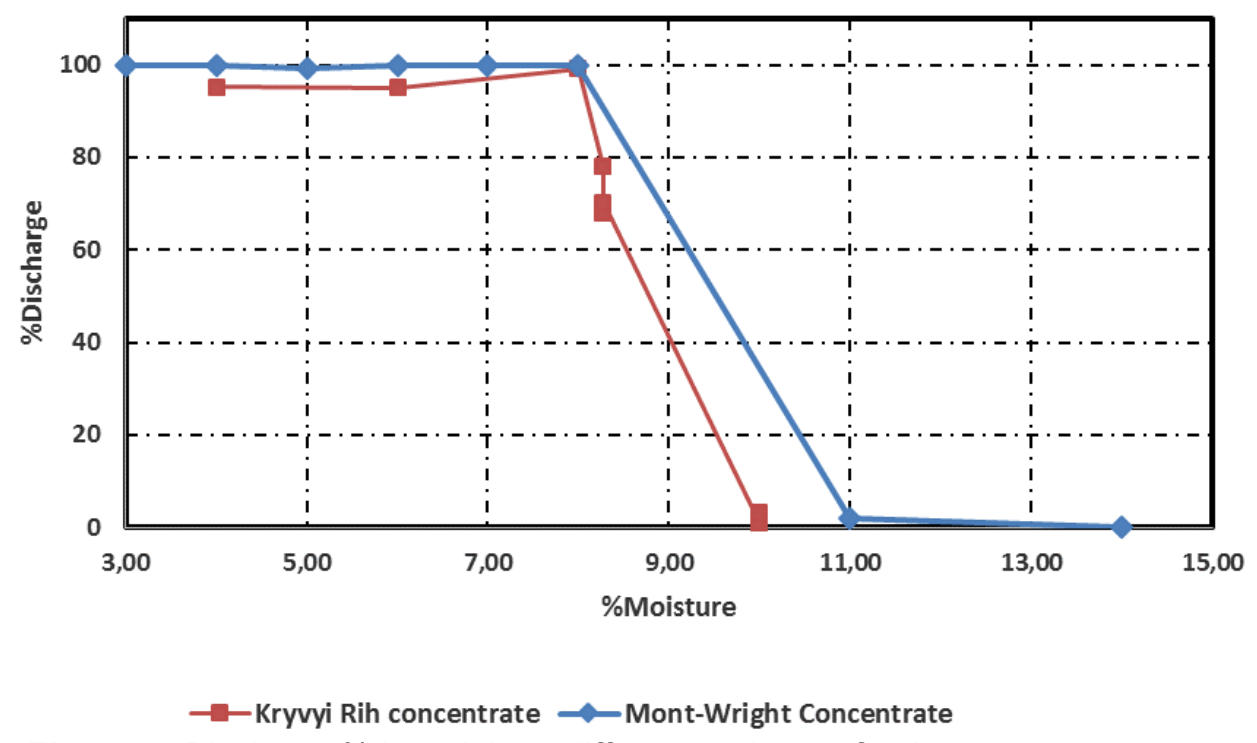

Figure 7: Discharge\% in weight at different moisture, for the two concentrates

\subsection{Effect of sodium polyacrylate}

The dry Kryvyi Rih concentrate was mixed with water to achieve the current moisture level $10.5 \%$; the dry Mont-Wright concentrate was mixed with water to achieve $5 \%$ 
moisture, in order to be situated in the worst case. The discharging efficiency was tested at different polymer dosage.

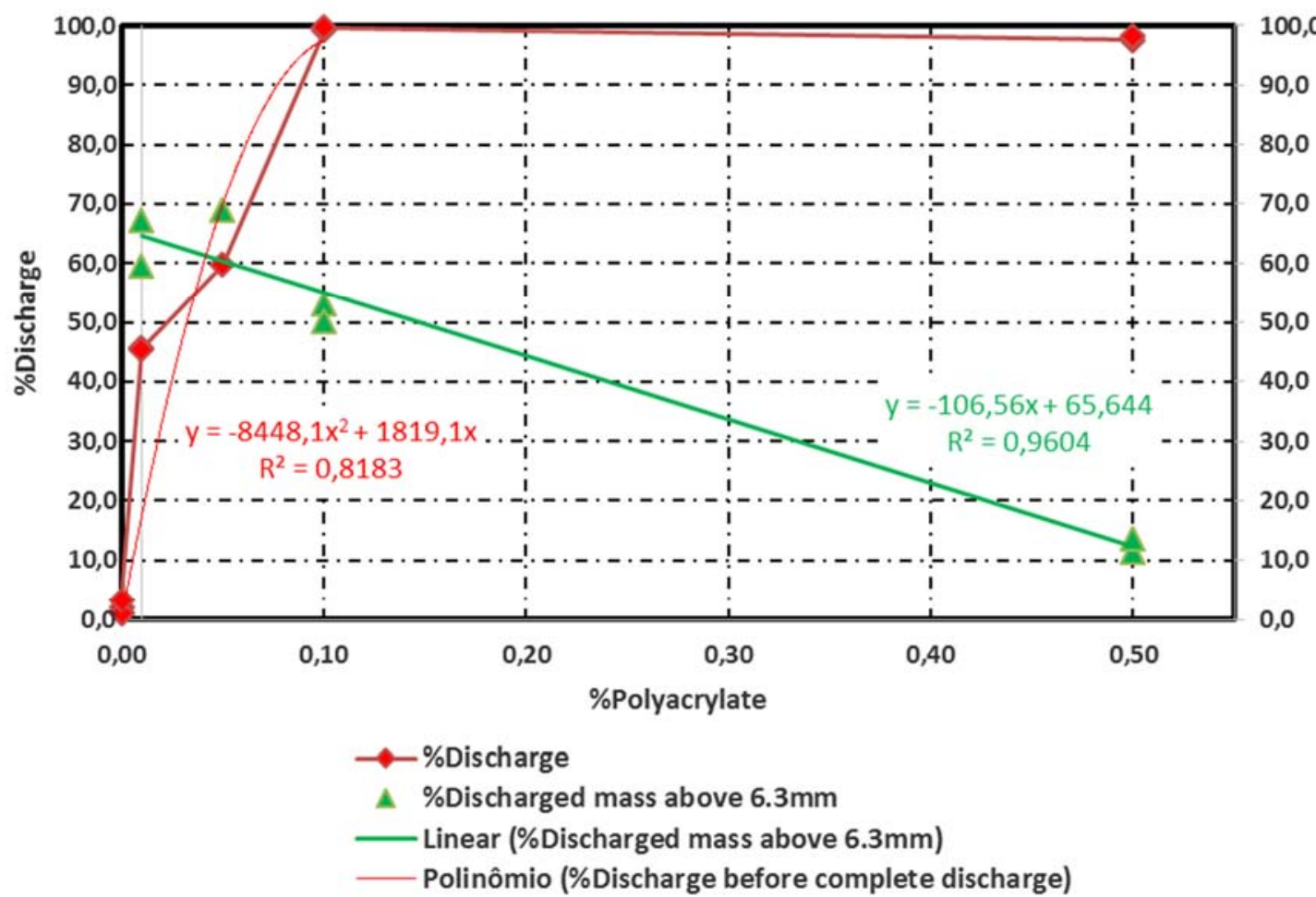

Figure 8: Discharge $\%$ in weight and $+6.3 \mathrm{~mm} \%$ in weight, at different polymer dosages for Kryvyi Rih concentrate

It can be concluded from Figure 8 that sodium polyacrylate Favor E3050 helps to discharge the Kryvyi Rih concentrate. At $0.1 \%$ addition, almost all the sample can be discharged. Higher polymer dosage can decrease the percentage of agglomerate. In the case of Mont-Wright concentrate, it can be seen in Table 4 that the discharging improves when the polymer dosage is higher; the discharged material is more disaggregated. On the other hand, only a single block can be discharged when no polymer is used.

Table 4: Discharging at different polymer dosage for Mont-Wright concentrate

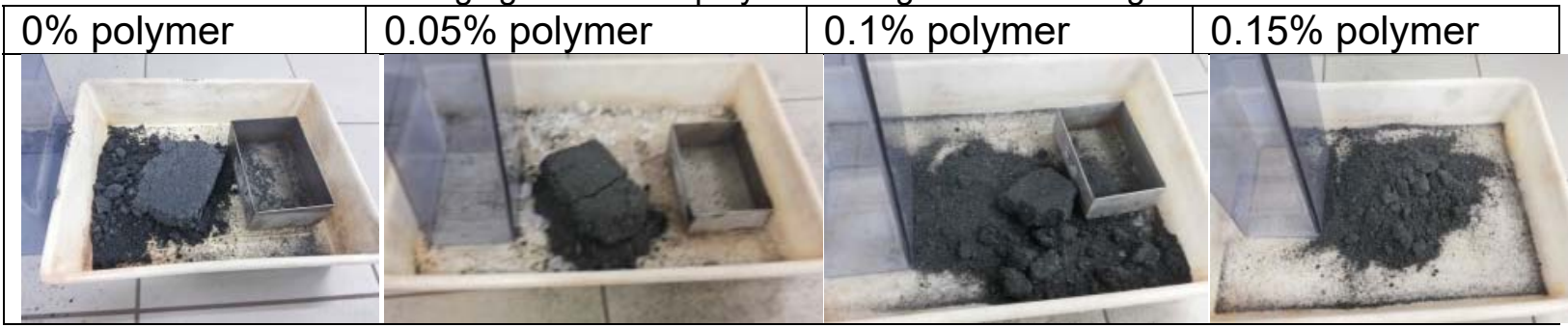

\subsection{Effect of bishofite solution}

Bishofite solution was tested for Kryvyi Rih concentrate. The solution was sprayed onto the inner wall of the steel box, as it has been performed onto the wagons in Kryvyi Rih. 


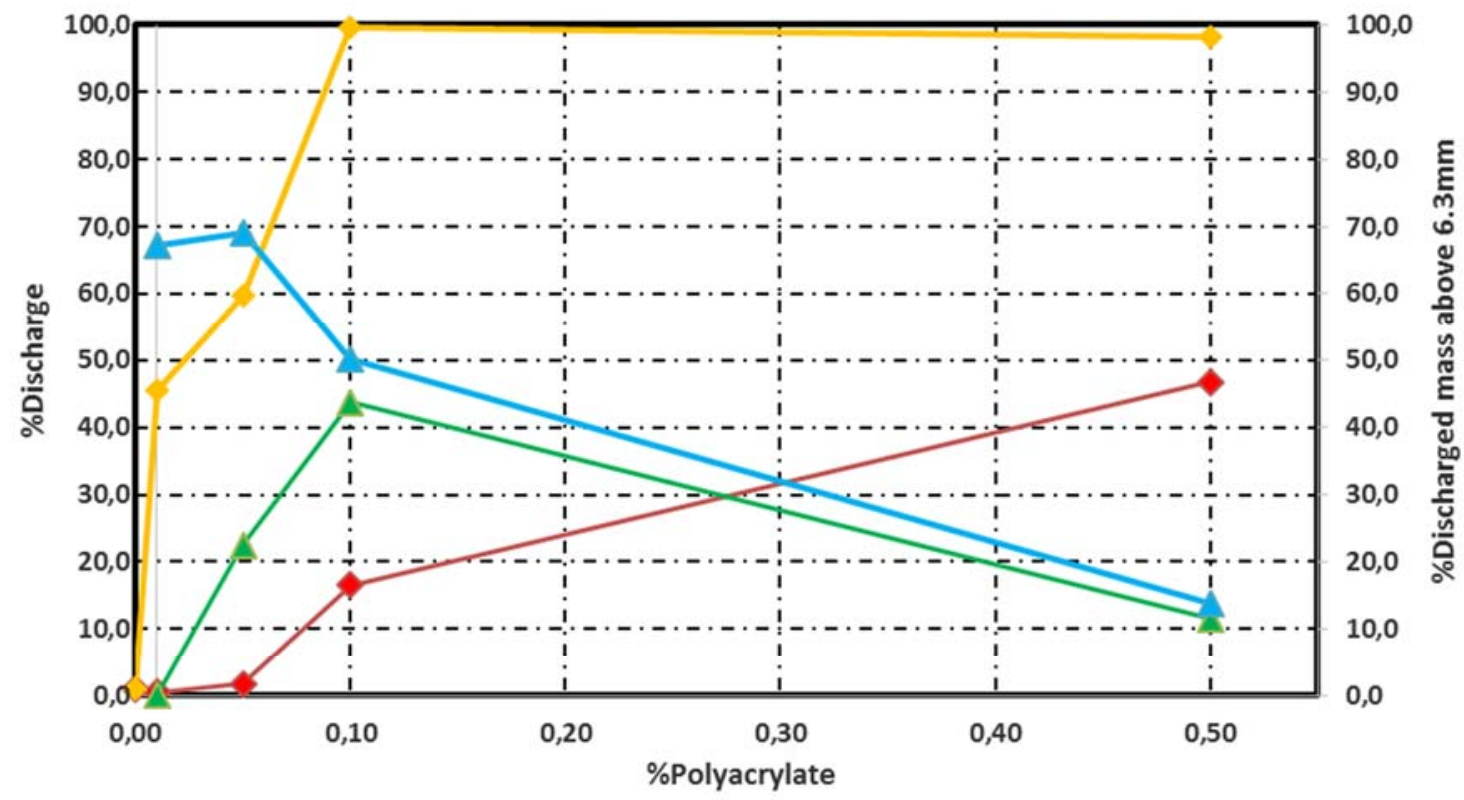

\section{$-\%$ Discharged mass with Bishofite solution \\ $-1-\%$ Discharged mass with Bishofite solution above $6.3 \mathrm{~mm}$ \\ $\ldots$ \%Discharged mass without Bishofite solution \\ $-\%$ Discharged mass without Bishofite solution above $6.3 \mathrm{~mm}$}

Figure 9: Effect of bishofite solution, with or without polyacrylate, for Kryvyi Rih concentrate

It can be concluded from Figure 9 that without polyacrylate, there is little difference in discharge $\%$ with or without bishofite solution. When polyacrylate is used, its discharging efficiency is decreased when bishofite is present. This can be explained by the fact that the water absorption capacity of polyacrylate is usually reduced, in a significant way, by the salinity in water. This is due to the osmotic pressure which is related to the ion concentration in the solution. In deionized water, water is absorbed by the polymer to lower the concentration of cations inside the polymer. When salt water is added to the polymer hydrogel, the electrolyte concentration outside of the polymer increases and water exits the polymer to equilibrate the concentration of cations. ${ }^{1}$ According to the above results, it was not tested for Mont-Wright concentrate.

\subsection{Effect of sodium polyacrylate without mixing}

As mixing requires supplementary cost, the possibility of applying the polymer without mixing was investigated. Two possibilities were tested: applying the polymer simply on the bottom of the wagon but in a homogeneous way, or mostly on the corners.
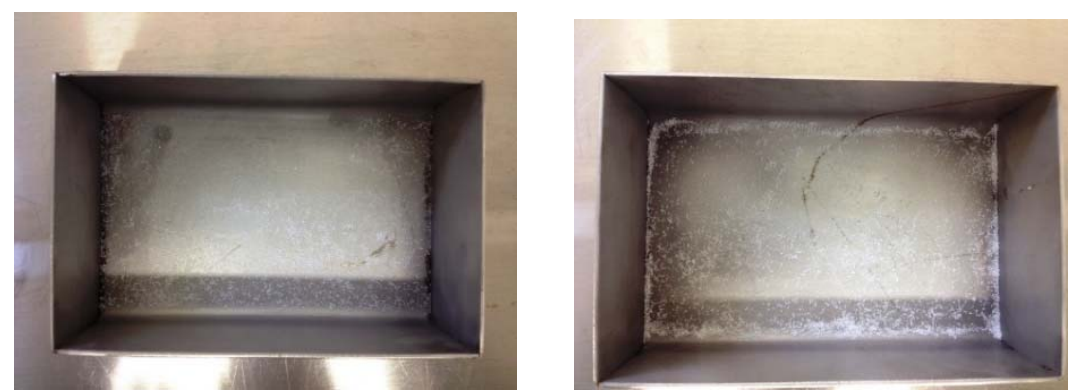

Figure 10: Application of polymer in a homogeneous way (left); or mostly in the corners (right) 


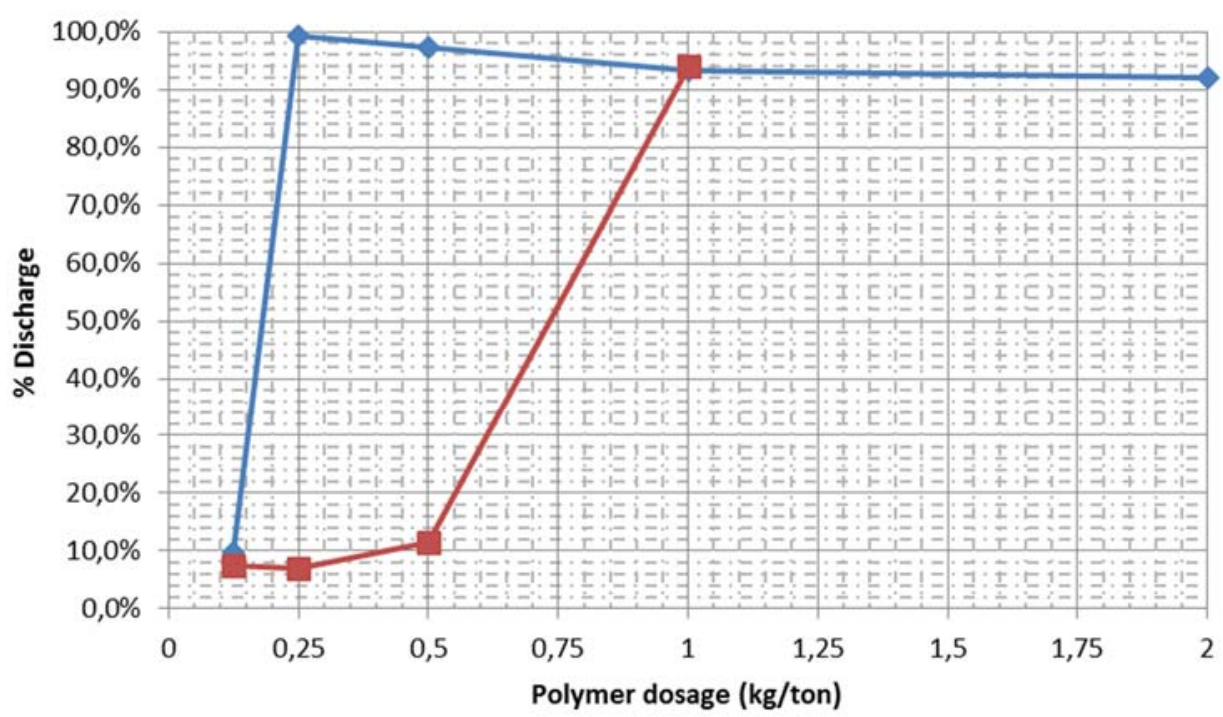

Figure 11: Effect of polymer dosage and distribution for Kryvyi Rih concentrate

In the case of Kryvyi Rih concentrate, it can be concluded from Figure 11 that:

- It is possible to apply the superabsorbent polymer only on the bottom of the boxes to avoid freezing.

- It is better to apply the superabsorbent in an homogeneous way, rather than to concentrate the application at the corners;

- The optimal dosage seems to be around $0.25 \mathrm{~kg} / \mathrm{ton}$, which should be confirmed by an industrial trial.

Table 5: Effect of polymer dosage and distribution for Mont-Wright concentrate

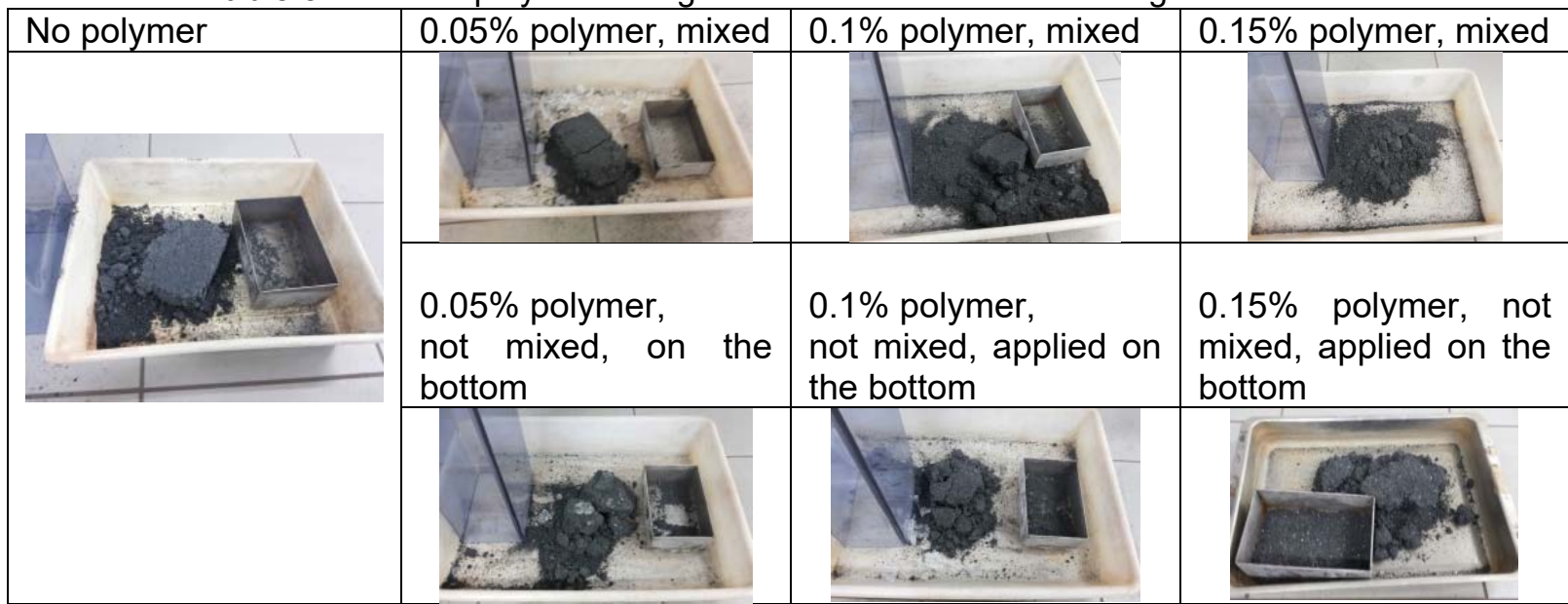

In the case of Mont-Wright concentrate, it can be concluded from Table 5 that it is possible to apply the superabsorbent polymer only on the bottom of the boxes to avoid freezing, but the discharging quality is slightly better when the iron ore is mixed with the polymer. At $0.05 \%$ dosage, the effect of mixing is not significant. This effect becomes important when the dosage is above $0.1 \%$.

In both cases, the polymer has the tendency to remain on the bottom of the steel box after discharging. This can largely reduce its potential impact on the metallurgical utilization of the iron ore, and makes the reutilization of the polymer in a new voyage feasible. 


\section{CONCLUSIONS}

It can be concluded that:

- Each iron ore concentrate has its critical moisture, above which the discharging in severe winter becomes an issue. It seems that this critical moisture is related to the particle size distribution.

- Super water absorbent polymer helps to discharge iron ore concentrate in freezing conditions, and helps to avoid discharging aggregates;

- Bishofite solution does not have significant effect on antifreezing, and can have detrimental effect on the superabsorbent polymer;

- The optimal dosage seems to be between $0.025-0.1 \%$ by weight or lower, which should be confirmed by an industrial trial;

- It is possible to apply the superabsorbent polymer only on the bottom of the boxes to avoid freezing, but the discharging quality is slightly better when the iron ore is mixed with the polymer;

- After discharging, the polymer has the tendency to remain on the wall, which largely reduces its potential impact on the metallurgical utilisation of the iron ore concentrate, and can probably be reused for new loads.

\section{Acknowledgements}

The authors are grateful to Ruslan Dobrovolskiy V (ArcelorMittal Kryvyi Rih), Eloi Godin (ArcelorMittal Mining Canada), Bogdan Cristea and Dobrin Craciun Toader (ArcelorMittal Galati Romania), Piotr Janik (ArcelorMittal Dąbrowa Górnicza Poland), Michal Rezak (ArcelorMittal Ostrava, Czech Republic) for their assistance in providing important information from industry.

Special thanks to Joanna Ploch and Annette Zurmuehlen (Evonik Nutrition \& Care $\mathrm{GmbH}$ ) for their suggestions and to Matthias Camarda (ArcelorMittal Maizieres Research) and Gabriela Luiza Pires Lage (Unviersidade Federal de Minas Gerais) for their help in the testwork. The professional and kind help of Yves Basselin, Géraldine Siboni, Marine Lacoste and Arnaud Pirson (ArcelorMittal Maizières Research) on characterization is also greatly appreciated.

\section{REFERENCES}

1 Atkins, Peter W.; de Paula, Julio "Section 5.5 (e)". Physical Chemistry. 9th edition. Oxford University Press; 2010 